days no virus was isolated in the samples obtained during the 79 days of experiment. An active growth of the virus was observed in the genital tracts of one boar since the titre of the viral suspension increased between two consecutive samplings. A possible virulicidal effect of semen on Aujeszky's virus was studied but could not be demonstrated. The short duration of the viral excretion was not due to an inactivation or neutralisation of the virus by the semen as the latter did not show any virulicidal effect and as no neutralizing activity could be observed in the different samples obtained.

\title{
Pig rotavirus enteritis in France
}

\author{
G. COR'THIER \\ Laboratoive de Pathologie Porcine, \\ Station de Virologie et d'Immunologie, I.N.R.A., \\ $7885^{\circ}$ Thiverval Grignon (France)
}

This paper is divided into two parts. The purpose of the first one was to give a general survey of pig rotavirus enteritis. The etiology, pathogeny, clinics, epidemiology, diagnosis and prophylaxy are discussed. The second part deals with the importance of this disease in France. The infection is observed very frequently: more than $83 \mathrm{p}$. I 00 of the pigs have a positive serology.

Rotavirus was isolated and characterized in some faeces of enteritic pigs. Inoculation of the different strains into colostrum deprived piglets led to lethal enteritis (death within 3 days).

\section{Swine dysentery, a disease due to spontaneous contamination in pens. Clinical data and diagnosis}

\author{
J. P. RAYNAUD, G. BRUNAULT, J. PHILIPPE;
}

Station de Recherche et de Développement Vétérinaive et Nutrition Animale, Pfizer International, 37400 Amboise (France)

Eighty three young weaned piglets weighing $19 \mathrm{~kg}$ on an average were put individually in pens already contaminated by dysenteric animals. 90 p. I 00 showed a typical disease and the morbidity was very high in those conditions. Among the dysenteric animals 80 p. too died and $20 \mathrm{p}$. Ioo were spontaneously cured. In animals which were going to die, dysentery occurred I 3 days after the beginning of the contamination and lasted 8 days. Before the death (23rd day) 2.5 days of diarrhoea plus mucus were noted (only $49 \mathrm{p}$. I 00 of the animals). In animals which were going to be cured spontaneously dysentery occurred on day 14 and lasted for to days. Before being completely cured (day 39) 92 p. Ioo of the animals - showed 7 days of diarthoea with mucus. To confirm the etiology it is useful to give an estimate of the presence of Treponema and Campylobacter on dried smears and to number Treponema and Balantidium coli on fresh smears. In a sure diagnosis of the disease it is necessary to isolate the Treponema hyodysenteriae. strain and to evidence its hemolytic properties and its pathogenicity in piglets. 